vision. In any case when an anæsthetic is administered by an unqualified person the doctor present must be held solely responsible for what happens.

I am, Sir, yours faithfully, Herbert WILITAMSON.

Queen Anne-street, W., Sept. 29th, 1919.

\section{TRANSMISSION OF INFECTIVE DISEASE BY SUCKLING.}

To the Editor of THE LaNCnT.

SIR,-The publication of Dr. H. Heiman's case in your issue of Oct. 11th (p. 653), has brought to my recollection a case of typhoid in a nursing mother with a four months' old infant I had some 12 years ago. A positive Widal was present and an enlarged spleen and rose spots. There was no history of an analogous previous attack. As the child had been breast-fed for the first 10 days of the illness, during which time the disease was unrecognised, I yielded to the importunities of the mother and consented to the breast feeding being continued. The mother's illness ran a mildish course and she continued nursing right through it, and the child escaped infection.

Three years ago I attended a lady in her second confinement, which was quite normal. Twenty-four hours after, her temperature,ran up and she exhibited a large crop of typical varicella spots. She then stated that she had noticed two spots on the abdomen on the day previous to her confinement. These spots also were found to be typical in character. On the beginning of the seventh day the infant developed a typical rash.

As the experience of years has shown the incubation period of varicella to be about 21 days, it seems to me that this case proves that the virus was transmitted via the placenta. I am, Sir, yours faithfully,

Chiswick, W., Oct. 13th, 1919. H. O. BUTLER.

\section{WAS ST. LUKE A PHYSICIAN? To the Editor of THE LANCET.}

SIR, - With respect to Professor H. J. Cadbury's opinion, quoted in the review of "The Style and Literary Method of Luke" in THE LANCET of Oct. 11th, that the use of medical terms by St. Luke does not justify the opinion of many scholars that he was necessarily a medical man, it is surely right to state that Harnack, whom he refers to, was the foremost biblical scholar in Germany, and declared that the evidence in favour of his professional knowledge was overwhelming. I would ask, Need we go further in discussing this matter than accept St. Paul's reference to his companion,

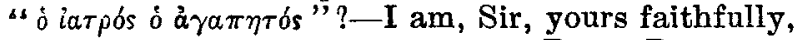

DXCE DUCKWORTH,

Oct. 12th, 1919. Vice-Provost, Guild of St. Luke.

\section{IONISATION FOR SEPSIS.}

\section{To the Editor of THE $\mathrm{LAN}$ CET.}

SIR,-I think the article by Captain F. W. Baker Young in your issue of Sept. 20 th and the letter by Dr. A. R. Friel in that of Oct. 4th need a comment by one who has long been interested in the effects of the constant current upon bacteria in liquids. In view of Captain Young's failure to find any description of apparatus for such observations may I call his attention to an article contributed by me to THE LANCET of July 3rd, 1909, on the Electrical Reactions of Bacteria. In this article a figure was given showing a slide which was filled with a bacterial suspension through which a current could be passed and the effects watched through a microscope. I also gave my reasons for abandoning such a method. Observations of that sort are liable to serious fallacy owing to the currents set up by surface tension variations and vortex effects due to the bursting of gas bubbles generated by the electric current. A second figure showed a simpler and better apparatus subsequently demonstrated at meetings of the Royal Society of Medicine, the British Medical Association's annual meeting, and at the Dresden Hygiene Exhibition in 1911 by Mr. Armit on my behalf.

Captain Young's results in the treatment of suppurating wounds by the use of electrolysis in saline solution confirm those obtained by Mr. C. R. C. Lyster and myself at the Middlesex Hospital in 1913, and mentioned in THE LANCET of Feb. 14lb, 1914.
In regard to Dr. Friel's letter, when reporting my findings of these bacterial movements to the Royal Society, $B$, vol. Ixxxi., 1909, I advanced the theory of an affinity between the chlorine ion and the bacterial envelope to account for the manifest movement. This theory is fortified by the observation that the velocity of the bacterial movement corresponds fairly well with the known ionic velocity. For the germicidal effect which soon ensued at the anodewhen using sodium chloride as the electrolyte-one need, I think, invoke no more than the lethal effect of chlorine upon bacteria. I am, Sir, yours faithfully, Charles Russ, M.B., M.R.C.S.

Beaumont-street, W., Oct. 11th, 1919.

\section{FALLACIES IN THE MEASUREMENT OF BODY-WEIGHT.}

\section{To the Editor of THE LANCET.}

SrR,-To weigh the body more often than once a day would be waste of time ; and it is, at least, doubtful whether daily weighings, even in fever, are worth their trouble. The following remarks are not concerned with that question, nor with the conclusions based upon daily weighings in Dr. MacNaught Scott's note on Diurnal Variation published in your last issue (Oct. 11th). They deal merely with the fallacies incidental to the customary weekly or fortnightly weighings as usually conducted. Bearing in mind that more than half of the weight of the body (and likewise of all solid food) is water, any variations in weight may be regarded as due, for the greater part, to variations in its water content. It is well known that the kidney is at times capable of abstracting water from the blood with great rapidity. Under the nervous influence of a variety of stresses -emotional, thermal, bowel-regulating, and others-it often happens that within 10 "minutes after thoroughly emptying the bladder a large quantity of urine is again discharged. That source of error in our reckonings is less difficult to avoid than that which arises from the daily variations in the output from the bowel. The remaining source of error is completely avoidable; it goes without saying that in all comparative clinical weighings the weight of the clothing should not be merely estimated approximately, but should be kept strictly identical. These considerations have led me to utilise the only opportunity within the 24 hours when optimum conditions can be secured in respect of those gross factors of error -namely, on rising from bed in the morning, before any thermal or other stresses have come in, before taking any food or drink, before evacuating the bowel; but always immediately after a complete emptying of the bladder, and always whilst wearing the same dressing-gown. This seems to be the best, and as I think the only reliable method for keeping a true record of genuine variations in body-weight. Even in hospital wards it can be carried out with little trouble if the weighing machine is mounted on wheels.

I am, Sir, yours faithfully,

Upper Brook-street, W., Oct. 11th, 1919. WILLIAM EWART.

\section{THE POSITION AND PAYMENT OF THE PENSIONS BOARDS. \\ To the Editor of THE LANCET.}

SrR,-In reply to the letter signed "Member of Pension Board" in your issue of Sept. 6th, complaining of the unnecessary amount of writing to be done by members of boards, may I remark that the possibility of the clerical staff doing more of this work is under consideration, I am informed. A letter has recently been circulated to this effect. The duplicate cards certainly give some extra work now, because, in order to fulfil their object, the summaries of all past boards have to be made and entered thereon; but when once this initial stage is passed writing work for the future should be much curtailed. All boards then would require the completion of only one $\mathrm{A} 36 / \mathrm{C}$ (which previously had to be rendered in duplicate), together with such summary as the president may see fit to dictate for each card. The suggestion that cards should be filled up in a quiet room by a capable medical man some time after the board would entail, I am given to understand, the addition of at least two medical men for each area of six boards. The objection that at present one or two pensioners less (per session) can be examined by each board should be counterbalanced later 